\title{
5-type HPV mRNA versus 14-type HPV DNA test: test performance, over-diagnosis and overtreatment in triage of women with minor cervical lesions
}

\author{
Bjørn Westre ${ }^{1}$, Anita Giske ${ }^{1}$, Hilde Guttormsen ${ }^{1}$, Sveinung Wergeland Sørbye ${ }^{2^{*}}$ and Finn Egil Skjeldestad ${ }^{3}$
}

\begin{abstract}
Background: Repeat cytology and HPV testing is used in triage of women with minor cytological lesions. The objective of this study was to evaluate 14-type HPV DNA and 5-type HPV mRNA testing in delayed triage of women with ASC-US/LSIL.

Methods: We compared a DNA test (Roche Cobas 4800) and an 5-type mRNA test (PreTect HPV-Proofer). In total 564 women were included in the study.

Results: The sensitivity among solved cases for CIN3+ were $100 \%$ (15/15) for both tests. The sensitivity for CIN2+ of the HPV DNA test was $100 \%$ (38/38) relative to $79 \%$ (30/38) for the 5-type HPV mRNA test. The corresponding estimates of specificity for CIN2+ among solved cases were $84 \%$ (393/466; $95 \% \mathrm{Cl}$ : 81-88) and $91 \%$ (451/498; $95 \%$ Cl: 88-93). The positive predictive values for CIN3+ were $13.5 \%$ (15/111) for DNA+ and $19.5 \%$ (15/77) for 5-type mRNA+. Significantly more women screened with 5-type mRNA than DNA returned to screening (81\% vs $71 \%, p<0.01$ ). Subsequently, significantly fewer women were referred for colposcopy/biopsies/treatment (19\% $(105 / 564)$ vs $29 \%(165 / 564), p<0.01)$.

Conclusions: 5-type HPV mRNA is more specific than 14-type HPV DNA in delayed triage of women with ASC-US/LSIL. The referral rate for colposcopy was $57 \%$ higher for DNA+ relative to mRNA+ cases (165 vs 105), with the same detection rate of $\mathrm{CIN} 3+$, but the 5-type mRNA test had lower sensitivity for CIN2+. It is important to consider the trade-off between sensitivity and specificity of the diagnostic test when designing screening algorithms.
\end{abstract}

Keywords: HPV, DNA, mRNA, Screening, Triage, CIN, CIN2, CIN3, Cervical cancer

\section{Background}

Cervical cancer is the third most common cancer in women worldwide [1]. Persistent infection of human papillomavirus (HPV) causes virtually all cases of cervical cancer [2]. In Europe most cervical cancer cases are caused by HPV types $16,18,31,33$, and $45[1,3]$. Cervical cancer can be prevented by early detection and treatment of precancerous lesions [4]. Women with minor cytological cervical lesions have an increased risk of having, or developing, high-grade dysplasia compared

\footnotetext{
* Correspondence: sveinung.sorbye@unn.no

${ }^{2}$ Department of Clinical Pathology, University Hospital of North Norway, 9038 Tromsø, Norway

Full list of author information is available at the end of the article
}

to women with normal cytology. However, most minor cytological lesions regress spontaneously, and therefore careful triage is crucial in order to avoid unnecessary referrals and overtreatment [5]. In Norway, HPV test is used in delayed triage of women with atypical squamous cells of undetermined significance (ASC-US) or low-grade squamous intraepithelial lesions (LSIL) [6]. If the HPV test is positive, the woman is referred to colposcopy.

The HPV E6/E7 mRNA test PreTect HPV-Proofer which detects HPV E6/E7 mRNA from the five most prevalent types causing cervical cancer has been shown to have a higher clinical specificity and positive predictive value (PPV) than HPV DNA tests [7-14]. A high specificity and a low positivity rate of a triage test indicates a low 


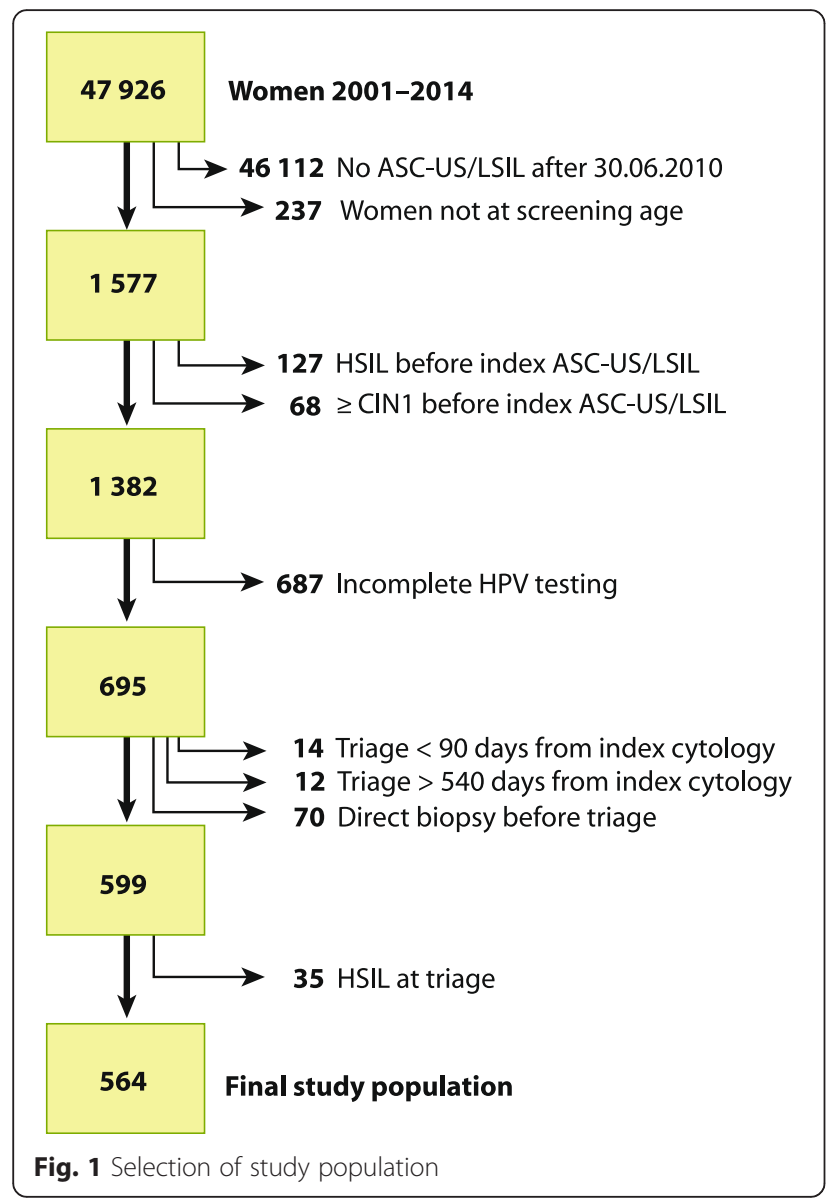

referral rate for colposcopy [8]. In this study we performed a direct comparison of a 5-type HPV mRNA and a 14type HPV DNA test in delayed triage of ASC-US/LSIL related to referral rates for colposcopy, biopsy rates, and histological outcomes.

\section{Methods}

Organized cervical cancer screening was introduced in Norway in 1995 with the recommendation that all women 25 to 69 years have a Pap smear collected every third year [15]. During the study period the Norwegian cervical cancer program recommended delayed triage with repeat cytology and HPV testing 6-12 months after the index diagnosis of ASC-US/LSIL. Women with highgrade squamous intraepithelial lesions (HSIL) or repeated ASC-US/LSIL with a positive HPV test were referred to colposcopy/biopsy immediately after triage. Women with a normal smear and a positive HPV test were recommended a repeat HPV test within 12 months, whereas women with an ASC-US/LSIL/normal smear with a negative HPV test were returned to the screening program at a three-year interval [9].

This study compared test performance of the HPV mRNA test PreTect HPV-Proofer (PreTect AS, Norway), which detects E6/E7 mRNA of 5 HPV types, and the HPV DNA test Cobas 4800 (Roche Molecular Diagnostics), which detects 14 HPV types. We followed the manufacturer's instructions in preparation of aliquots and detection of mRNA, while we analyzed HPV DNA in accordance with national guidelines [10]. The conventional cytology

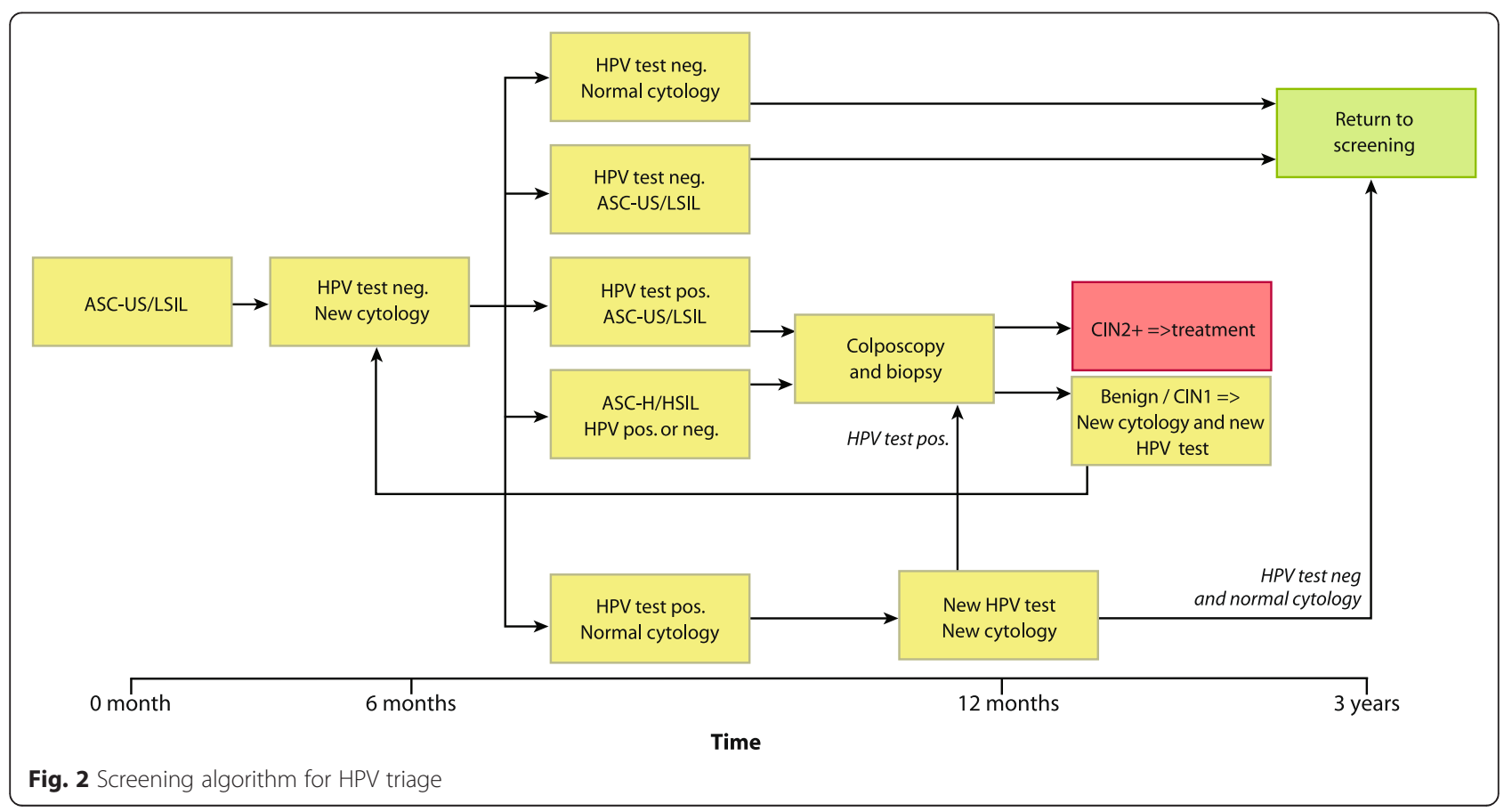


Table 1 Outcome of triage by HPV test $(n=564)$

\begin{tabular}{|c|c|c|c|c|}
\hline & \multicolumn{2}{|l|}{ DNA } & \multicolumn{2}{|c|}{ 5-type-mRNA } \\
\hline & $N=564$ & $\%(95 \%$ Cl) & $N=564$ & $\%(95 \% \mathrm{Cl})$ \\
\hline Back to screening & 399 & $70.7(66.9-74.5)$ & 459 & $81.4(78.2-84.6)^{*}$ \\
\hline Met for biopsy & 105 & $18.6(15.4-21.8)$ & 77 & $13.7(10.9-16.5)$ \\
\hline Scheduled, not met for biopsy & 36 & $6.4(4.4-8.4)$ & 15 & $2.7(1.4-4.0)^{*}$ \\
\hline Incomplete follow-up & 24 & $4.3(2.6-6.0)$ & 13 & $2.3(1.1-3.5)$ \\
\hline
\end{tabular}

*p $<0.05$

Triage repeat cytology and HPV test 3-18 months after index ASC-US/LSIL cytology

DNA HPV DNA test (Cobas 4800)

5-type-mRNA HPV mRNA test (PreTect HPV-Proofer)

(Pap smear) consists of sampling cells from the cervical area. The sample is obtained using a brush, and the cells are placed directly onto a glass slide and spray fixed. Then the same brush is placed into a liquid medium (ThinPrep, Cytyc Corporation, Marlborough, USA) for HPV testing. In Norway, many hospitals have switched from conventional Pap smears to liquid-based cytology (LBC), but Ålesund Hospital still uses conventional Pap smears.

The Department of Pathology, Ålesund Hospital, located on the western coast of Norway, serves a background population of approximately 50000 women at screening age 25-69 years and assesses 12000 cervical smears annually. Since 1999 the department has used the clinical database SymPathy for administration of cytological and histological specimens. From January 1, 2001, through September 15, 2014, we identified 47926 women with 160466 valid smears, among which 1577 women had a diagnosis of ASC-US/LSIL after June 30, 2010. Our study commenced on January 4, 2012, when the department introduced the HPV DNA test. After excluding women with a history of HSIL, or biopsy with cervical intraepitelial neoplasi grade 1 or worse (CIN1+), those under 25 or over 69 years of age, and cases with none or only one HPV test, 695 women were eligible for study participation (Fig. 1).

The Norwegian cervical cancer screening program recommended triage 6 to 12 months after the index ASC-US/LSIL [6, 9] (Fig. 2). We expanded the triage follow-up window from 90 to 540 days after the index

Table 2 Most severe histology from biopsy/cone specimen by HPV test

\begin{tabular}{llllll}
\hline Histology & \multicolumn{2}{l}{ HPV DNA } & & \multicolumn{2}{c}{ 5-type-mRNA } \\
\cline { 2 - 3 } & $N=105$ & $\%(95 \% \mathrm{Cl})$ & & $N=77$ & $\%(95 \% \mathrm{Cl})$ \\
\hline Normal/CIN1 & 67 & $63.8(54.6-73.0)$ & & 47 & $61.0(50.1-71.9)$ \\
CIN2 & 23 & $21.9(14.0-29.8)$ & & 15 & $19.5(10.7-28.3)$ \\
CIN3+ & 15 & $14.3(7.6-21.0)$ & & 15 & $19.5(10.7-28.3)$ \\
\hline
\end{tabular}

CIN cervical intraepitelial neoplasi

HPV DNA HPV DNA test (Cobas 4800)

5-type-mRNA HPV mRNA test (PreTect HPV-Proofer) smear. Therefore women having triage $<90$ days $(n=14)$ or $>540$ days $(n=12)$ after index smear, and women having direct biopsy (reflex testing) before or at triage $(n=70)$, and women who had HSIL at triage $(n=35)$ were excluded, leaving 564 women for final analyses. Either a positive HPV DNA or a positive HPV mRNA test triggered colposcopy.

We defined solved cases as subjects who returned to the screening program from either a valid smear/negative HPV test, or having had a biopsy, which determined future follow-up/treatment. Corresponding dates were "outcome" dates for solved cases, while we censored cases not met for biopsy or incomplete follow-up at last day of study, September 15, 2014. Abnormal cervical cytology was classified using the Bethesda system. Cervical biopsies were reported using WHO histological classification of tumors of the uterine cervix (http://screening.iarc.fr/colpochap.php?chap $=2$ ). All biopsies were reviewed by one experienced pathologist (BW). Biopsies with uncertain cellular changes were immunostained with p16 (INK4a) (Roche mtm laboratories AG). If there was a discrepancy between biopsy and treatment histology, the most severe histology was endpoint.

The sensitivity of the HPV tests is defined as the proportion of high-grade dysplasia (CIN2+) detected by the two different HPV tests. In the calculations of specificity, it is assumed that HPV negative samples without detected dysplasia during the follow-up period were disease-free.

All analyses were done in SPSS, version 22.0, with Chi-square test for categorical variables, $t$-test for continuous variables, and survival analyses for clinically solved cases. Significance level was set to $p<0.05$.

\section{Results}

At index cytology $84 \%(473 / 564)$ were ASC-US and $16 \%(91 / 564)$ LSIL. At the most recent screen prior to index cytology $79 \%(444 / 564)$ of the women had a normal cytology within the screening interval, $4 \%(24 / 564)$ had a normal cytology beyond the screening interval, whereas index cytology represented the first smear, ever, 
Table 3 Test performance of HPV DNA test $(N=504)$ and 5-type-mRNA test $(N=536)$ in solved cases

\begin{tabular}{llll}
\hline Triage status & CIN2+ & CIN1- & Total \\
HPV DNA positive & 38 & 73 & $111^{\text {a }}$ \\
HPV DNA negative & 0 & 393 & 393 \\
Total & 38 & 466 & 504 \\
Triage status & CIN2+ & CIN1- & Total \\
HPV mRNA positive & 30 & 47 & 77 \\
HPV mRNA negative & 8 & 451 & 459 \\
Total & 38 & 498 & 536 \\
\hline
\end{tabular}

CIN2+ CIN2, CIN3, ACIS, and cervical cancer

CIN1- Normal and CIN1

${ }^{a}$ Of the 111 women with a positive HPV DNA test, six women had normal cytology and a negative HPV DNA test at second follow-up and returned to screening at 3-year interval

for $17 \%(96 / 564)$ of the women. The mean age was 39 years (SD 10.5 years) and nearly $40 \%$ (217/564) of the women were 25-34 years of age.

Mainly from triage, but also after follow-up of a normal cytology with a positive HPV test at triage, the 5type mRNA test scheduled significantly more women back to screening, $81 \%(459 / 564)$, than the DNA test, $71 \%(399 / 564)(p<0.01)$. There was no difference in incomplete follow-ups by screening test, HPV DNA test $4 \%(24 / 564) / \mathrm{mRNA}$ test $2 \%(13 / 564)(p=0.09)$. Accordingly, the DNA test targeted significantly more women for biopsy, $25 \%(141 / 564)$ than the 5-type mRNA test, $16 \%(92 / 564)(p<0.01)$ (Table 1$)$. In total 141 women were recommended colposcopy by the DNA test, and 105 (74\%) met for biopsy. Out of the 92 women scheduled for biopsy by the 5-type mRNA test, $77(84 \%)$ made a visit $(p=0.12)$.
There was no difference in histology outcome by screening test among women who had biopsy and/or treatment. Both tests identified 14 women with CIN3 and one woman with squamous cell carcinoma (Table 2). The positive predictive value (PPV) for CIN2+ was $34 \%$ (38/111) for HPV DNA and $39 \%$ (30/77) for the 5-type mRNA test. The PPVs for CIN3+ were $13.5 \%(15 / 111)$ and $19.5 \%(15 / 77)$ for the DNA and the 5-type mRNA test (Table 3). The increased referral rate to biopsy among DNA-tested women relative to mRNA-tested women resulted in 10 more cases of normal histology, 10 more cases of CIN1, and eight more cases of CIN2 (Table 4).

At triage, $65 \%(386 / 564)$ were negative in both tests (DNA-/mRNA-), while $29 \%(165 / 564)$ and $19 \%$ (105/ $564)$ were positive with the DNA or 5-type mRNA test, respectively. In total, 98 women were double positive (DNA+/mRNA+). Among the $73 \mathrm{HPV}$ DNA positive and 5-type mRNA negative women (DNA+/mRNA-), 69 were positive for HPV types other than 16 and 18, two for HPV16, and two for HPV18. Among women with a negative HPV DNA test, seven tests were positive with the 5-type mRNA test (DNA-/mRNA+), four HPV16 and three HPV other than 16 and 18. Among the 53 women testing positive for HPV16 (DNA+ and/or mRNA+), 44 tested positive in both tests (DNA +/mRNA+), 48 tested positive for HPV DNA, and 49 for 5-type mRNA. Similar results for HPV18, 11 women out of 14 were double positive (DNA+/mRNA +), 13 tested positive for HPV DNA, while 12 tested positive for 5-type mRNA. The largest difference was for HPV other types than HPV16 and HPV18. Only 39 out of 116 tested positive in both tests (DNA +/mRNA+), 110 tested positive for DNA, and 44 tested positive for 5-type mRNA.

Table 4 HPV positivity, genotype, and HPV test by stage of triage and histology

\begin{tabular}{|c|c|c|c|c|c|c|c|c|c|c|}
\hline & \multicolumn{5}{|c|}{ HPV DNA } & \multicolumn{5}{|c|}{ 5-type-mRNA } \\
\hline & & HPVNeg. & HPV 16 & HPV 18 & HPV other & & HPVNeg. & HPV 16 & HPV 18 & HPV other \\
\hline Stages of triage & $N$ & $\%$ & $\%$ & $\%$ & $\%$ & $\mathrm{~N}$ & $\%$ & $\%$ & $\%$ & $\%$ \\
\hline At triage $\mathrm{a}^{\mathrm{a}}$ & 564 & 69.7 & 8.5 & 2.3 & 19.5 & 564 & 81.4 & 8.7 & 2.1 & 7.8 \\
\hline Recommended biopsy & 141 & & 28.4 & 8.5 & 63.1 & 92 & & 45.7 & 10.9 & 43.5 \\
\hline Had biopsy ${ }^{c}$ & 105 & & 36.2 & 7.6 & 56.2 & 77 & & 51.9 & 9.1 & 39.0 \\
\hline By histology & $\mathrm{N}$ & & $\%$ & $\%$ & $\%$ & $\mathrm{~N}$ & & $\%$ & $\%$ & $\%$ \\
\hline Normal/CIN1 & 67 & & 26.9 & 7.5 & 65.7 & 47 & & 44.7 & 8.5 & 46.8 \\
\hline CIN2 & 23 & & 39.1 & 13.0 & 47.8 & 15 & & 53.3 & 20.0 & 26.7 \\
\hline CIN3 & 14 & & 71.4 & 0.0 & 28.6 & 14 & & 71.4 & 0.0 & 28.6 \\
\hline Sq. cell carcinoma & 1 & & 0.0 & 0.0 & 100 & 1 & & 0.0 & 0.0 & 100 \\
\hline
\end{tabular}

HPV DNA other HPV type 31, 33, 35, 39, 45, 51, 52, 56, 58, 59, 66, and 68

5-type-mRNA other HPV type 31, 33, and 45

CIN cervical intraepitelial neoplasi

${ }^{a}$ The Norwegian cervical cancer screening program recommended triage 6 to 12 months after the index ASC-US/LSIL

${ }^{b}$ Women with either a positive HPV DNA or a positive HPV mRNA test are recommended biopsy

In total 141 women were recommended colposcopy by the DNA test, and 105 (74\%) met for biopsy. Out of the 92 women scheduled for biopsy by the 5-type mRNA test, $77(84 \%)$ made a visit $(p=0.12)$ 
Table 4 summarizes HPV positivity, genotype, stage of triage and histology by HPV test. The DNA test detected 23 cases of CIN2, relative to 15 with the 5-type mRNA test. There was concordance between tests in eight cases of HPV16, three cases of HPV18, and three cases of HPV other than 16 and 18. One CIN2 case testing HPV16 in the DNA test tested HPV other than 16 and 18 in the 5-type mRNA test. The eight additional cases of CIN2 detected by the DNA test were all negative for HPV 16/18 and positive for other than 16 and 18: three in the age group 25-34 years and five in the 35-69 group. All cases with CIN3 $(n=14)$ were concordant for HPV type in both tests ( $n=10$ for HPV16, $n=4$ for HPV other than 16 or 18$)$.

In total $89 \%(504 / 564)$ of the DNA cases were solved across the time frame of the study, relative to $95 \%$ (536/ $564)$ of the 5 -type mRNA-tested cases $(p<0.01)$. The cumulative proportions of cases solved within 12 and 36 months were significantly higher for 5-type mRNAtested subjects, $92 \%$ (95\% CI: 90-94) and $96 \%$ (95\% CI: 94-98), than DNA-tested subjects, 85 \% (95\% CI: 82-88) and $90 \%$ (95 \% CI: 87-93)).

The sensitivity among solved cases for CIN2+ of the HPV DNA test was $100 \%(38 / 38)$ relative to $79 \%$ (30/ 38, $95 \%$ CI: 67-92) for the 5-type mRNA test. The corresponding estimates of specificity among solved cases were $84 \%$ (393/466, $95 \%$ CI: 81-88), and $91 \%$ (451/ 498, 95 \% CI: 88-93) (Table 3) $(p<0.01)$. In Tables 5, 6 , 7 and 8 we provide data on triage cytology (ASC-US or LSIL) by HPV test for CIN2+ and CIN3 + .

\section{Discussion}

Our study shows that the 5-type HPV mRNA test had significantly lower positivity rate $(19 \%)$ than the 14-type HPV DNA test (29\%), which led to a significantly higher referral rate to colposcopy for the HPV DNA test. Both tests diagnosed equal numbers of women with CIN3+, whereas the DNA test detected eight more cases of

Table 5 Test performance of HPV DNA test and 5-type HPV mRNA test in repeated ASC-US in solved cases versus CIN2+

\begin{tabular}{llll}
\hline Triage status & CIN2+ & CIN1- & Total \\
HPV DNA positive & 25 & 62 & 87 \\
HPV DNA negative & 0 & 28 & 28 \\
Total & 25 & 90 & 115 \\
Triage status & CIN2+ & CIN1- & Total \\
HPV mRNA positive & 18 & 45 & 63 \\
HPV mRNA negative & 5 & 45 & 50 \\
Total & 23 & 90 & 113 \\
\hline CIN2
\end{tabular}

CIN2+ CIN2, CIN3, ACIS, and cervical cancer

CIN1- Normal and CIN1
Table 6 Test performance of HPV DNA test and 5-type HPV mRNA test in repeated ASC-US in solved cases versus CIN3+

\begin{tabular}{llll}
\hline Triage status & CIN3+ & CIN2- & Total \\
HPV DNA positive & 9 & 78 & 87 \\
HPV DNA negative & 0 & 28 & 28 \\
Total & 9 & 106 & 115 \\
Triage status & CIN3+ & CIN2- & Total \\
HPV mRNA positive & 9 & 54 & 63 \\
HPV mRNA negative & 0 & 50 & 50 \\
Total & 9 & 104 & 113 \\
\hline
\end{tabular}

CIN2+ CIN2, CIN3, ACIS, and cervical cancer

CIN1- Normal and CIN1

CIN2. All these CIN2 cases were of HPV types other than $16 / 18$ in both tests, and they were negative for HPV mRNA 31, 33, and 45.

In agreement with other studies, the positivity rate of the HPV DNA test in triage of ASC-US/LSIL is nearly double compared to the 5-type HPV mRNA test (Table 9 $[6,7,10-12,16])$. We found a $57 \%$ higher referral rate using HPV DNA versus 5-type mRNA while others have reported a double referral rate ratio using HPV DNA compared to 5-type mRNA $[6,7,10]$.

Most studies report a higher sensitivity for CIN2+ and CIN3+ using the HPV DNA test or 14-type HPV mRNA test (Hologic APTIMA) compared to the 5-type HPV mRNA test, whereas the specificity is significantly higher for 5-type HPV mRNA compared to HPV DNA (or 14type HPV mRNA test) $[6,7,16-18]$. The higher specificity reflects the higher positive predictive value (PPV) for the HPV 5-type mRNA test relative to the HPV DNA test (or 14-type HPV mRNA test).

The major difference in test performance between the DNA and the 5-type mRNA test was HPV types other than 16/18, which were in most cases HPV mRNAnegative for $31 / 33 / 45$. The choice of test is crucial to

Table 7 Test performance of HPV DNA test and 5-type HPV mRNA test in repeated LSIL in solved cases versus CIN2+

\begin{tabular}{llll}
\hline Triage status & CIN2+ & CIN1- & Total \\
HPV DNA positive & 13 & 31 & 44 \\
HPV DNA negative & 0 & 5 & 5 \\
Total & 13 & 36 & 49 \\
Triage status & CIN2+ & CIN1- & Total \\
HPV mRNA positive & 12 & 17 & 29 \\
HPV mRNA negative & 1 & 19 & 20 \\
Total & 13 & 46 & 49 \\
\hline
\end{tabular}

CIN2+ CIN2, CIN3, ACIS, and cervical cancer

CIN1- Normal and CIN1 
Table 8 Test performance of HPV DNA test and 5-type HPV mRNA test in repeated LSIL in solved cases versus CIN3+

\begin{tabular}{llll}
\hline Triage status & CIN3+ & CIN2- & Total \\
HPV DNA positive & 6 & 38 & 44 \\
HPV DNA negative & 0 & 5 & 5 \\
Total & 6 & 43 & 49 \\
Triage status & CIN3+ & CIN2- & Total \\
HPV mRNA positive & 6 & 23 & 29 \\
HPV mRNA negative & 0 & 20 & 20 \\
Total & 6 & 43 & 49 \\
\hline
\end{tabular}

CIN2+ CIN2, CIN3, ACIS, and cervical cancer

CIN1- Normal and CIN1

avoid over-diagnosis in triage of women with minor cytological lesions. Our data indicates that the difference in sensitivity/loss of CIN2 may be attributed to HPV types with a low oncogenic potential with slow progression into cancer. The next screening round will capture these women for follow-up/treatment if there is any progression. A triage HPV test with high specificity, targeting the HPV types with the highest potential for progression to cervical cancer, will reduce over-diagnosis and overtreatment, as observed in this study. Overdiagnosis is a cost-driver in unnecessary conizations and may lead to an increased risk of premature births and late abortions in subsequent pregnancies $[19,20]$ in this young population.

In our study the 5-type HPV mRNA test detected the same number of CIN3+, with a significant lower positivity rate and significant lower referral rate to colposcopy than the HPV DNA test. The risk of cervical cancer in women with ASC-US/LSIL is low and even lower if the HPV mRNA test is negative [6, 16, 21]. In Europe, HPV16 predominates in both CIN3 and cervical cancer. Other HPV types have a slower progression into cancer [22]. In countries with an organized cervical cancer screening program the risk of development of cervical cancer is higher for HPV types 16, 18, 31, 33 and 45 than for other HPV types [23]. These observations support the use of a specific HPV mRNA test detecting the five main HPV types in triage of women with minor cytological lesions.

In a meta-analysis of the accuracy of 5-type HPV mRNA tests, the pooled sensitivity for CIN2+ of the 10 included studies was $75 \%$ and $76 \%$ for the triage of ASC-US and LSIL, respectively [14]. It is well known that many cervical lesions with moderate or severe dysplasia will regress spontaneously. Only $5 \%$ of women with CIN2 will develop cervical cancer without treatment [24]. Only $31 \%$ of colposcopically visible lesions with CIN3 will progress to invasive cancer within 30 years [25]. About $40 \%$ of CIN2 will regress within two years, and the regression rate of CIN2 caused by other HPV types than HPV type 16 is even higher [26]. It is probable that the 5-type HPV mRNA test in triage of women with minor cervical lesions identifies the majority of the lesions that are destined to progress to cancer $[27,28]$. When women with ASC-US/LSIL and a negative 5-type mRNA test are returned to screening in three years, we can reduce overtreatment of women with CIN1-2 caused by HPV types with a low risk of progression $[22,23,26,29]$.

Table 9 Test-performance of the 5-type mRNA test and 13-14 types DNA tests in delayed triage and reflex testing of women with minor cytological lesions and CIN3+ as outcome

\begin{tabular}{|c|c|c|c|c|c|c|c|c|c|c|c|c|c|c|c|}
\hline \multirow[t]{2}{*}{ Ref. } & \multirow{2}{*}{$\begin{array}{l}\text { Data } \\
\text { collection }\end{array}$} & \multirow[t]{2}{*}{ Year publ. } & \multirow[t]{2}{*}{ Country } & \multirow{2}{*}{$\begin{array}{l}\text { Study } \\
\text { design }\end{array}$} & \multirow{2}{*}{$\begin{array}{l}\text { Timing } \\
\text { HPV test }\end{array}$} & \multirow{2}{*}{$\begin{array}{l}\text { Length } \\
\text { f-up (mo) }\end{array}$} & \multirow{2}{*}{ Diagnosis } & \multirow[t]{2}{*}{ HPV test } & \multirow[t]{2}{*}{$\mathrm{N}$} & \multirow{2}{*}{$\begin{array}{l}\text { N HPV } \\
\text { positive }\end{array}$} & \multirow{2}{*}{$\begin{array}{l}\text { N Met } \\
\text { for biopsy }\end{array}$} & \multicolumn{4}{|c|}{ CIN3+ } \\
\hline & & & & & & & & & & & & Sens. & Spes. & PPV & NPV \\
\hline 6 & $\begin{array}{l}\text { July } 2005- \\
\text { Dec. } 2009\end{array}$ & 2013 & Norway & $\begin{array}{l}\text { Case- } \\
\text { series }\end{array}$ & $\begin{array}{l}\text { Delayed } \\
\text { triage }\end{array}$ & $\leq 36$ & $\begin{array}{l}\text { Repeat } \\
\text { ASCUS/LSIL }\end{array}$ & $\begin{array}{l}\mathrm{HC} \| \\
5 \text { mRNA }\end{array}$ & $\begin{array}{l}2150 \\
1543\end{array}$ & $\begin{array}{l}1504 \\
510\end{array}$ & $\begin{array}{l}1184 \\
435\end{array}$ & NR & & & \\
\hline 7 & $\begin{array}{l}\text { Jan. 2004- } \\
\text { Dec. } 2006\end{array}$ & 2011 & Italy & $\begin{array}{l}\text { Head-to- } \\
\text { head }\end{array}$ & $\begin{array}{l}\text { Reflex } \\
\text { testing }\end{array}$ & $\leq 2$ & $\begin{array}{l}\text { ASCUS/ } \\
\text { LSIL }\end{array}$ & $\begin{array}{l}\mathrm{HC} \| \\
5 \text { mRNA }\end{array}$ & $\begin{array}{l}795 \\
755\end{array}$ & $\begin{array}{l}614 \\
204\end{array}$ & $\begin{array}{l}377 \\
132\end{array}$ & NR & & & \\
\hline 10 & $\begin{array}{l}\text { Jan. } 2012- \\
\text { Sept. } 2012\end{array}$ & 2014 & Norway ${ }^{a}$ & $\begin{array}{l}\text { Head-to- } \\
\text { head }\end{array}$ & $\begin{array}{l}\text { Delayed } \\
\text { triage }\end{array}$ & $\leq 33$ & $\begin{array}{l}\text { Repeat } \\
\text { ASCUS/LSIL }\end{array}$ & $\begin{array}{l}\text { COBAS } \\
5 \text { mRNA }\end{array}$ & $\begin{array}{l}281 \\
281\end{array}$ & $\begin{array}{l}92 \\
37\end{array}$ & $\begin{array}{l}65 \\
26\end{array}$ & $\begin{array}{l}100 \\
75.0\end{array}$ & $\begin{array}{l}77.8 \\
91.6\end{array}$ & $\begin{array}{l}6.2 \\
11.5\end{array}$ & $\begin{array}{l}100 \\
99.6\end{array}$ \\
\hline 11 & $\begin{array}{l}\text { Aug. 2005- } \\
\text { Jan. } 2007\end{array}$ & 2008 & UK & $\begin{array}{l}\text { Head-to- } \\
\text { head }\end{array}$ & $\begin{array}{l}\text { Reflex } \\
\text { testing }\end{array}$ & $\begin{array}{l}\text { Same } \\
\text { day }\end{array}$ & $\begin{array}{l}\leq \text { mild } \\
\text { dyskaryosis }\end{array}$ & $\begin{array}{l}\mathrm{HC} \| \\
5 \text { mRNA }\end{array}$ & $\begin{array}{l}567 \\
558\end{array}$ & NR & $\mathrm{NRe}$ & $\begin{array}{l}100 \\
89.4\end{array}$ & $\begin{array}{l}26.0 \\
72.8\end{array}$ & $\begin{array}{l}11.1 \\
23.2\end{array}$ & $\begin{array}{l}100 \\
\text { NR }\end{array}$ \\
\hline 12 & $\begin{array}{l}\text { Sept. 2007- } \\
\text { Oct. } 2009\end{array}$ & 2012 & UK & $\begin{array}{l}\text { Head-to- } \\
\text { head }\end{array}$ & $\begin{array}{l}\text { Reflex } \\
\text { Testing }\end{array}$ & $\begin{array}{l}\text { Same } \\
\text { day }\end{array}$ & $\begin{array}{l}\leq \text { mild } \\
\text { dyskaryosis }\end{array}$ & $\begin{array}{l}\mathrm{HC} \| \\
5 \text { mRNA }\end{array}$ & $\begin{array}{l}670 \\
641\end{array}$ & $\begin{array}{l}526 \\
272\end{array}$ & NRe & $\begin{array}{l}100 \\
80.9\end{array}$ & NR & $\begin{array}{l}9.2 \\
16.6\end{array}$ & $\begin{array}{l}100 \\
\text { NR }\end{array}$ \\
\hline 16 & $N R$ & 2010 & Canada & $\begin{array}{l}\text { Head-to- } \\
\text { head }\end{array}$ & $\begin{array}{l}\text { Reflex } \\
\text { testing }\end{array}$ & $\leq 6$ & $\begin{array}{l}\text { ASCUS/ } \\
\text { LSIL }\end{array}$ & $\begin{array}{l}\mathrm{HC} \| \\
5 \text { mRNA }\end{array}$ & $\begin{array}{l}781 \\
781\end{array}$ & $\begin{array}{l}619 \\
328\end{array}$ & NRe & NR & & & \\
\hline A & $\begin{array}{l}\text { Jan. } 2012- \\
\text { Sep. } 2013\end{array}$ & & Norway ${ }^{a}$ & $\begin{array}{l}\text { Head-to- } \\
\text { head }\end{array}$ & $\begin{array}{l}\text { Delayed } \\
\text { testing }\end{array}$ & $\leq 33$ & $\begin{array}{l}\text { Repeat } \\
\text { ASCUS/LSIL }\end{array}$ & $\begin{array}{l}\text { COBAS } \\
5 \text { mRNA }\end{array}$ & $\begin{array}{l}564 \\
564\end{array}$ & $\begin{array}{l}171 \\
105\end{array}$ & $\begin{array}{l}105 \\
77\end{array}$ & $\begin{array}{l}100 \\
100\end{array}$ & $\begin{array}{l}80.0 \\
85.2\end{array}$ & $\begin{array}{l}13.9 \\
16.3\end{array}$ & $\begin{array}{l}100 \\
100\end{array}$ \\
\hline
\end{tabular}

A Present study

Sens Sensitivity; Spes. Specificity; PPV positive predictive value; NPV negative predictive value; NR Not reported; NRe Not relevant. All women had colposcopy regardless of HPV result

${ }^{a}$ Only solved cases are included in test-performance analysis 
The experience in the Department of Pathology, Alesund Hospital, is that the 5-type HPV mRNA test has a high specificity and a high positive predictive value. This makes it useful for triage of women with minor cervical lesions.

\section{Conclusions}

5-type HPV mRNA is more specific than HPV DNA in triage of women with repeated ASC-US/LSIL. The referral rate for colposcopy after repeated ASC-US/LSIL was $57 \%$ higher for DNA+ relative to mRNA+ cases, with the same detection rate of CIN3+. It is important to consider the trade-off between sensitivity and specificity of the diagnostic test when designing screening algorithms.

\begin{abstract}
Abbreviations
ASC-H, atypical squamous cells - cannot exclude HSIL; ASC-US, atypical squamous cells of undetermined significance; CIN, cervical intraepithelial neoplasia, also known as cervical dysplasia; CIN1, CIN2, CIN3, cervical intraepithelial neoplasia grade 1,2 or 3, also known as low grade, moderate or severe cervical dysplasia; CIN2+, CIN2, CIN3, adenocarcinoma in situ (ACIS) or cervical cancer DNA: Deoxyribonucleic acid; HPV, human papillomavirus; HPV DNA test, cobas 4800 detects DNA from 14 high-risk HPV types $(16,18$, $31,33,35,39,45,51,52,56,58,59,66$ and 68 ) at clinically relevant infection levels; HPV mRNA test, PreTect HPV-Proofer detects E6/E7 mRNA of 5 HPV types $(16,18,31,33$ and 45$) ; H S I L$, High grade squamous intraepithelial lesion; LBC, liquid-based cytology; LSIL, low grade squamous intraepithelial lesion; mRNA, messenger RNA; NPV, negative predictive value; Pap smear, the Papanicolaou test, also known as Pap test, cervical smear or cervical cytology; PPV, positive predictive value; RNA, ribonucleic acid; WHO, the World Health Organization
\end{abstract}

\section{Acknowledgements}

Not applicable.

\section{Funding}

This research was supported by a grant from the Helse Møre og Romsdal Trust. The funders had no role in study design, data collection and analysis, decision to publish, or preparation of the manuscript.

\section{Availability of data and materials}

The data will not be made available in order to protect the participants identity.

\section{Authors' contributions}

BW, SWS and FES participated in the design of the study. AG and HG screened all the PAP-smears and performed HPV mRNA testing. BW reviewed all the histological diagnosis. SWS and FES performed the statistical analysis. All authors read and approved the final manuscript.

\section{Authors' information}

Not applicable.

\section{Competing interests}

The authors declare that they have no competing interests.

\section{Consent for publication}

Not applicable.

\section{Ethics approval and consent to participate}

The Regional Committee for Medical and Health Research Ethics, North Norway, has approved the protocol as a quality assurance study in laboratory work fulfilling the requirements for data protection procedures within the department (2012/276/REK Nord). Norwegian regulations exempt quality assurance studies from written informed consent from the patients (https:// lovdata.no/dokument/SF/forskrift/2000-12-15-1265).

\section{Author details}

'Department of Pathology, Ålesund Hospital, Møre and Romsdal Health Trust, Ålesund, Norway. ${ }^{2}$ Department of Clinical Pathology, University Hospital of North Norway, 9038 Tromsø, Norway. ${ }^{3}$ Research Group Epidemiology of Chronic Diseases, Department of Community Medicine, UiT The Arctic University of Norway, Tromsø, Norway.

Received: 8 February 2016 Accepted: 1 June 2016

Published online: 07 June 2016

\section{References}

1. Arbyn M, Castellsague X, de Sanjose S, Bruni L, Saraiya M, Bray F, et al. Worldwide burden of cervical cancer in 2008. Ann Oncol. 2011;12:2675-86.

2. Ramakrishnan S, Partricia S, Mathan G. Overview of high-risk HPV's 16 and 18 infected cervical cancer: pathogenesis to prevention. Biomed Pharmacother. 2015;70:103-10

3. de Sanjose S, Quint WG, Alemany L, Geraets DT, Klaustermeier JE, Lloveras B, et al. Human papillomavirus genotype attribution in invasive cervical cancer: a retrospective cross-sectional worldwide study. Lancet Oncol. 2010;11:1048-56.

4. Saslow D, Solomon D, Lawson HW, Killackey M, Kulasingam SL, Cain J, et al. American Cancer Society, American Society for Colposcopy and Cervical Pathology, and American Society for Clinical Pathology screening guidelines for the prevention and early detection of cervical cancer. Am J Clin Pathol. 2012;137:516-42.

5. Arbyn M, Martin-Hirsch P, Buntinx F, Van Ranst M, Paraskevaidis E, Dillner J. Triage of women with equivocal or low-grade cervical cytology results: a meta-analysis of the HPV test positivity rate. J Cell Mol Med. 2009;13:648-59.

6. Nygard M, Roysland K, Campbell S, Dillner J. Comparative effectiveness study on human papillomavirus detection methods used in the cervical cancer screening programme. BMJ Open. 2014;4:e003460.

7. Benevolo M, Vocaturo A, Caraceni D, French D, Rosini S, Zappacosta R, Terrenato I, Ciccocioppo L, Frega A, Giorgi Rossi P. Sensitivity, specificity, and clinical value of human papillomavirus (HPV) E6/E7 mRNA assay as a triage test for cervical cytology and HPV DNA test. J Clin Microbiol. 2011;49(7):2643-50. doi:10.1128/JCM.02570-10.

8. Koliopoulos G, Chrelias C, Pappas A, Makridima S, Kountouris E, Alepaki M, Spathis A, Stathopoulou V, Panayiotides I, Panagopoulos P, Karakitsos P, Kassanos D. The diagnostic accuracy of two methods for E6\&7 mRNA detection in women with minor cytological abnormalities. Acta Obstet Gynecol Scand. 2012;91(7):794-801. doi:10.1111/j.1600-0412.2012.01414.x.

9. Sorbye SW, Fismen S, Gutteberg T, Mortensen ES. Triage of women with minor cervical lesions: data suggesting a "test and treat" approach for HPV E6/E7 mRNA testing. PLoS One. 2010;5:e12724.

10. Sorbye SW, Fismen S, Gutteberg TJ, Mortensen ES, Skjeldestad FE. HPV mRNA is more specific than HPV DNA in triage of women with minor cervical lesions. PLoS One. 2014;9:e112934.

11. Szarewski A, Ambroisine L, Cadman L, Austin J, Ho L, Terry G, et al. Comparison of predictors for high-grade cervical intraepithelial neoplasia in women with abnormal smears. Cancer Epidemiol Biomarkers Prev. 2008;17:3033-42.

12. Szarewski A, Mesher D, Cadman L, Austin J, Ashdown-Barr L, Ho L, et al. Comparison of seven tests for high-grade cervical intraepithelial neoplasia in women with abnormal smears: the Predictors 2 study. J Clin Microbiol. 2012;50:1867-73.

13. Trope A, Sjoborg K, Eskild A, Cuschieri K, Eriksen T, Thoresen S, et al. Performance of human papillomavirus DNA and mRNA testing strategies for women with and without cervical neoplasia. J Clin Microbiol. 2009;47:2458-64.

14. Verdoodt F, Szarewski A, Halfon P, Cuschieri K, Arbyn M. Triage of women with minor abnormal cervical cytology: meta-analysis of the accuracy of an assay targeting messenger ribonucleic acid of 5 high-risk human papillomavirus types. Cancer Cytopathol. 2013;121:675-87.

15. Nygård JF, Skare GB, Thoresen SO. The cervical cancer screening programme in Norway, 1992-2000: changes in Pap smear coverage and incidence of cervical cancer. J Med Screen. 2002;9:86-91.

16. Ratnam S, Coutlee F, Fontaine D, Bentley J, Escott N, Ghatage P, et al. Clinical performance of the PreTect HPV-Proofer E6/E7 mRNA assay in comparison with that of the Hybrid Capture 2 test for identification of women at risk of cervical cancer. J Clin Microbiol. 2010;48:2779-85.

17. Arbyn M, Ronco G, Anttila A, Meijer CJ, Poljak M, Ogilvie G, et al. Evidence regarding human papillomavirus testing in secondary prevention of cervical cancer. Vaccine. 2012;30 Suppl 5:F88-99. 
18. Arbyn M, Roelens J, Cuschieri K, Cuzick J, Szarewski A, Ratnam S, et al. The APTIMA HPV assay versus the Hybrid Capture 2 test in triage of women with ASC-US or LSIL cervical cytology: a meta-analysis of the diagnostic accuracy. Int J Cancer. 2013;132:101-8.

19. Arbyn M, Kyrgiou M, Simoens C, Raifu AO, Koliopoulos G, Martin-Hirsch P, et al. Perinatal mortality and other severe adverse pregnancy outcomes associated with treatment of cervical intraepithelial neoplasia: meta-analysis. BMJ. 2008;337:a1284. doi:10.1136/bmj.a1284:a1284.

20. Bruinsma FJ, Quinn MA. The risk of preterm birth following treatment for precancerous changes in the cervix: a systematic review and meta-analysis. BJOG. 2011;118:1031-41.

21. Sorbye SW, Fismen S, Gutteberg TJ, Mortensen ES. HPV mRNA test in women with minor cervical lesions: experience of the University Hospital of North Norway. J Virol Methods. 2010;169:219-22.

22. Tjalma WA, Fiander A, Reich O, Powell N, Nowakowski AM, Kirschner B, et al. Differences in human papillomavirus type distribution in high-grade cervical intraepithelial neoplasia and invasive cervical cancer in Europe. Int J Cancer. 2013;132:854-67.

23. Powell NG, Hibbitts SJ, Boyde AM, Newcombe RG, Tristram AJ, Fiander AN. The risk of cervical cancer associated with specific types of human papillomavirus: a case-control study in a UK population. Int J Cancer. 2011:128:1676-82.

24. Ostor AG. Natural history of cervical intraepithelial neoplasia: a critical review. Int J Gynecol Pathol. 1993;12:186-92.

25. McCredie MR, Sharples KJ, Paul C, Baranyai J, Medley G, Jones RW, et al. Natural history of cervical neoplasia and risk of invasive cancer in women with cervical intraepithelial neoplasia 3: a retrospective cohort study. Lancet Oncol. 2008;9:425-34.

26. Castle PE, Schiffman M, Wheeler CM, Solomon D. Evidence for frequent regression of cervical intraepithelial neoplasia-grade 2. Obstet Gynecol. 2009:113:18-25.

27. Basu P, Roychowdhury S, Bafna UD, Chaudhury S, Kothari S, Sekhon R, et al. Human papillomavirus genotype distribution in cervical cancer in India: results from a multi-center study. Asian Pac J Cancer Prev. 2009;10:27-34.

28. Kraus I, Molden T, Holm R, Lie AK, Karlsen F, Kristensen GB, et al. Presence of E6 and E7 mRNA from human papillomavirus types 16, 18, 31, 33, and 45 in the majority of cervical carcinomas. J Clin Microbiol. 2006:44:1310-7.

29. Zappacosta R, Gatta DM, Marinucci P, Capanna S, Lattanzio G, Caraceni D, et al. Role of E6/E7 mRNA test in the diagnostic algorithm of HPV-positive patients showing ASCUS and LSIL: clinical and economic implications in a publicly financed healthcare system. Expert Rev Mol Diagn. 2015;15:1-14.

\section{Submit your next manuscript to BioMed Central and we will help you at every step:}

- We accept pre-submission inquiries

- Our selector tool helps you to find the most relevant journal

- We provide round the clock customer support

- Convenient online submission

- Thorough peer review

- Inclusion in PubMed and all major indexing services

- Maximum visibility for your research

Submit your manuscript at www.biomedcentral.com/submit

C Biomed Central 